Article

\title{
Integration of Reversible Heat Pumps in Trigeneration Systems for Low-Temperature Renewable District Heating and Cooling Microgrids
}

\author{
Luca Urbanucci $^{1}{ }^{\oplus}$, Daniele Testi ${ }^{1, *(\mathbb{C})}$ and Joan Carles Bruno ${ }^{2}$ \\ 1 DESTEC Department of Energy, Systems, Territory and Constructions Engineering, University of Pisa, \\ Largo L. Lazzarino, 56122 Pisa, Italy \\ 2 Department of Mechanical Engineering, Universitat Rovira i Virgili, Avda. Països Catalans 26, \\ 43007 Tarragona, Spain \\ * Correspondence: daniele.testi@unipi.it
}

Received: 21 June 2019; Accepted: 31 July 2019; Published: 5 August 2019

check for updates

\begin{abstract}
District heating and cooling networks based on trigeneration systems and renewable energy technologies are widely acknowledged as an energy efficient and environmentally benign solution. These energy systems generally include back-up units, namely fossil-fuel boilers and electric chillers, to enhance system flexibility and cover peak energy demand. On the other hand, 4th generation district heating networks are characterized by low-temperature water distribution to improve energy and exergy efficiencies. Moreover, reversible heat pumps are a versatile technology, capable of providing both heating and cooling, alternately. In this paper, the integration of reversible heat pumps as single back-up units in hybrid renewable trigeneration systems serving low-energy micro-district heating and cooling networks is investigated. A detailed modeling of the system is provided, considering part-load and ambient condition effects on the performance of the units. Size and annual operation of the proposed system are optimized in a case study, namely a large office building located in Pisa (Italy), by means of a genetic algorithm-based procedure. A comparison with the conventional trigeneration system is performed in terms of economic and environmental perspectives. Results show that the integration of reversible heat pumps is an economically viable solution capable of reducing by $7 \%$ the equivalent annual cost, increasing the installed power of renewables up to $23 \%$, and lowering by $11 \%$ carbon dioxide emissions, compared to the energy system with conventional back-up units.
\end{abstract}

Keywords: reversible heat pumps; trigeneration; renewable energy; district heating and cooling; smart energy systems; optimization

\section{Introduction}

Energy consumption worldwide grew by $2.3 \%$ in 2018, due in large part to higher heating and cooling needs. As a result, global energy-related $\mathrm{CO}_{2}$ emissions increased by $1.7 \%$, up to $33.1 \mathrm{Gt} / \mathrm{yr}$. Energy efficiency and renewable energy sources (RES) are considered the main weapons to reduce carbon dioxide emissions in the energy sector and improve primary energy intensity [1].

In this context, Smart Energy Systems (SES) are acknowledged as a viable and effective solution to shift to a more sustainable energy paradigm [2]. Smart energy systems aim to optimally integrate different energy sectors (i.e., electricity, heating, cooling, industry, transportation), in order to improve the overall flexibility and efficiency. In this way, both the economic viability and environmental sustainability of energy systems can be enhanced.

Within this framework, Distributed Energy Systems (DES), which bring the production of energy close to end-users, are a clear opportunity to realize the smart integration of different energy technologies 
and sources [3]. Likewise, District Heating and Cooling (DHC) networks are key elements in achieving higher security of supply, lower costs, and lower carbon dioxide emissions [4]. Indeed, smart thermal grids can exploit hybrid substations (e.g., distributed heat pumps) and usually implement optimal control strategies, thus fostering the coupling between the electrical and thermal grids [5].

In recent years, the concept of 4 th generation district heating (4GDH) has emerged, which outlines the main features that modern thermal grids must have to meet the challenges of a sustainable energy system [6]. The first and foremost feature is the low temperature of the water distribution, so that grid losses are lowered, heat from low-temperature and renewable sources can be exploited, and high-efficiency technology, such as heat pumps, can be integrated within the network. In this respect, several works can be found in recent literature. Sameti and Haghighat [7] proposed a mathematical programming model to optimize design and planning of a $4 \mathrm{GDH}$, from an economic perspective. Cai et al. [8] demonstrated that lower supply temperatures can improve the energy efficiency of thermal networks, by analyzing the operation of electric heat boosters in low-energy districts. Likewise, a case study was investigated by Baldvinsson and Nakata [9], which proved that lower temperatures provide higher exergy efficiency in district heating systems.

At the same time, the issue of possible layouts of DES and plants feeding DHC networks has been thoroughly investigated in recent years. Indeed, the optimization problem of SES must deal with the synthesis of the plant, i.e., the existence and size of each component/technology considered in the superstructure of the energy system [10]. The possibility of integrating RES in district cooling systems has been exhaustively reviewed in [11]. Soltero et al. [12] analyzed biomass-based district heating systems, combining forestry biomass and agriculture residues as fuel. Testi et al. [13] proposed the adoption of distributed heat pumps to assist the thermal production at building level in a hybrid microgrid. The integration of a trigeneration system with an Organic Rankine Cycle and a ground source heat pump was studied by Kang et al. [14]. Possible configurations and operational modes of heat pumps in district heating systems have been proposed and analyzed by Ommen et al. [15] and by Sayegh et al. [16]. Similarly, Ostergaard et al. [17] investigated the effect of the introduction of heat pumps in small-scale district heating systems.

Basic trigeneration systems feeding DHC networks are traditionally composed of a prime mover (e.g., an internal combustion engine), a heat recovery system, and a thermally driven cooling technology (usually an absorption chiller). Moreover, back-up units are included in the system, to ensure that the demand can always be met and to improve the flexibility of the system. Generally, those back-up units are electrically driven chillers and fossil-fuel boilers, for the cooling and heating loads, respectively [18]. Nevertheless, fossil-fuel boilers are exergetically inefficient, especially when the temperature of the delivered heat is low, as in $4 \mathrm{GDH}$.

On the other hand, electrically driven reversible heat pumps are a versatile technology, capable of providing both heating and cooling, alternately [19-21]. Furthermore, among other factors, the performance of heat pumps is highly dependent on the supply temperature; therefore, this technology is especially suitable for low-temperature heating applications. Moreover, unlike fossil-fuel boilers, electric heat pumps represent a hub between the electric and thermal networks, thus enhancing system flexibility and integration of RES.

In view of all this, this paper aims to investigate the integration of reversible electric heat pumps in trigeneration systems, as single back-up units to replace traditional fossil-fuel boilers and non-reversible electric chillers. An energy supply system for a district heating and cooling microgrid integrating RES is considered, consisting of an internal combustion engine, a single-effect absorption chiller, a reversible electric heat pump, photovoltaic panels, and a wind turbine. The thermal network serves office buildings equipped with fan coil terminals, thus requiring low-temperature heat. Energy demand data from a case study located in Pisa, Italy, are considered. The integrated optimal sizing and hourly operation of the proposed system are evaluated from the economic point of view. A two-level optimization algorithm is developed: the optimal operation problem is solved by exhaustive search, while a genetic algorithm is applied to the sizing problem. Moreover, a comparison with the conventional trigeneration 
system (i.e., with fossil-fuel boiler and non-reversible electric chiller) is also performed in terms of economic and environmental perspectives.

\section{Methodology}

\subsection{The Energy System}

As mentioned, the main purpose of this work is the comparison of two different configurations of trigeneration system integrating renewable energy sources. The schematics of the energy systems are shown in Figure 1. Both configurations comprise an internal combustion engine (ICE) as the cogeneration unit, an absorption chiller (AC), photovoltaic panels (PV), and a wind turbine (WT). The main difference between the configurations lies in the back-up units. In the traditional trigeneration system, a natural-gas boiler (B) and a non-reversible electric chiller (EC) assist the heating and cooling production, respectively, while, in the proposed configuration, a reversible heat pump (RHP) is included as single back-up unit for both thermal demands.

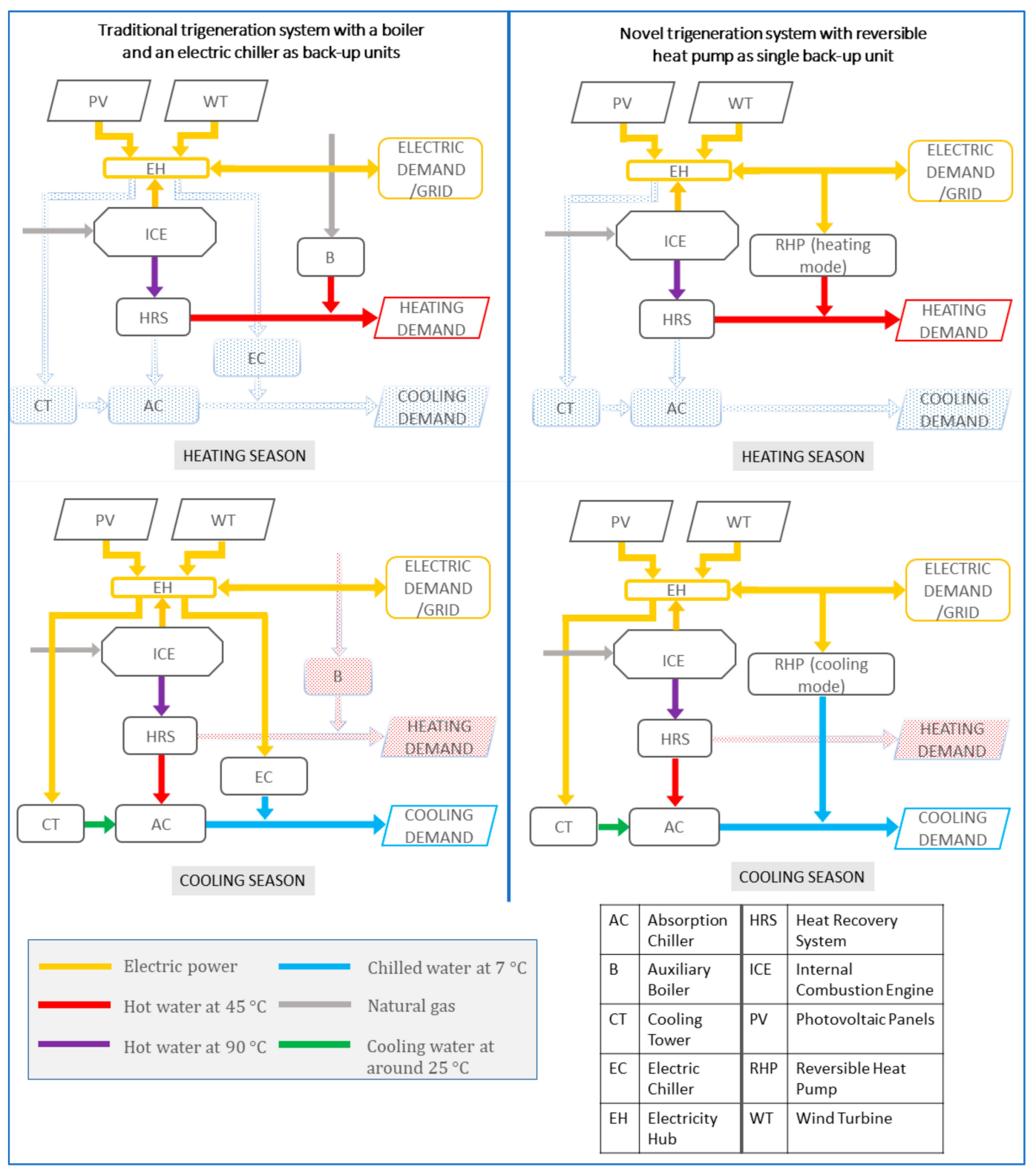

Figure 1. Schematics of the compared energy systems. 


\subsection{Subsystem Models}

In this subsection, models and features adopted for the components of the simulated energy system are described.

The cogeneration unit is a spark ignition reciprocating internal combustion engine fueled by natural gas. Part-load efficiencies have been considered [22] and shown in Figure 2, where the load factor is defined as $L_{I C E}=E_{I C E} / E_{I C E, n o m}$. The heat recovery system recovers heat from the exhaust gas, jacket cooling water system and lube oil of the ICE in the form of hot water at around $90^{\circ} \mathrm{C}$. The power capacity lower bound has been set to $50 \%$ of the nominal power capacity.

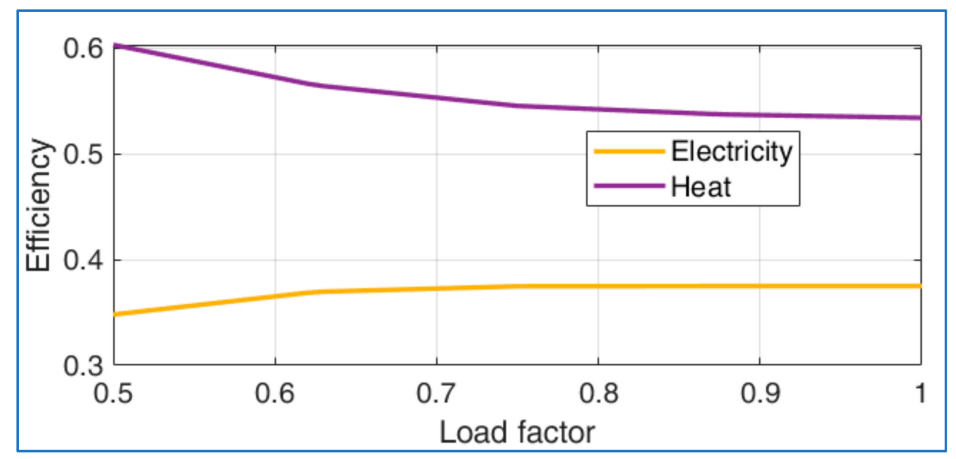

Figure 2. Part-load efficiencies of the ICE.

The reversible heat pump and the non-reversible electric chiller are air-to-water units. The single-effect absorption chiller, fed by the hot water recovered from the ICE, has a cooling tower as heat sink. The heat pump and the chillers have been modelled considering both ambient temperature and part-load condition effects on the coefficient of performance. The so-called "locally constant exergy efficiency" (or Carnot efficiency) approach allows to consider how the temperature of the thermal sources affects the performance of the heat pump/chiller. Moreover, part-load behavior can be considered by a correction factor. The coefficient of performance (COP) of the units is expressed as the product of the ideal COP (i.e., the COP of the Reversed Carnot Cycle), the exergy efficiency (defined as the ratio between the actual COP of the unit and the ideal COP at those thermal source temperatures), and a part-load correction factor [18]:

$$
C O P=C O P_{i d} \cdot \eta_{e x} \cdot C F
$$

The ideal COP of the electrically driven heat pumps under the heating and cooling modes are, respectively:

$$
\begin{gathered}
C O P_{R H P-H, i d}=\left(T_{\text {hot }}+273.15\right) /\left(T_{\text {hot }}-T_{\text {cold }}\right) \\
C O P_{R H P-C, i d / E C, i d}=\left(T_{\text {cold }}+273.15\right) /\left(T_{\text {hot }}-T_{\text {cold }}\right)
\end{gathered}
$$

The ideal COP of the absorption chiller is:

$$
\operatorname{COP}_{A C, \text { id }}=1-\frac{\left(T_{\text {hot }}+273.15\right)}{\left(T_{\text {gen }}+273.15\right)} / 1-\frac{\left(T_{\text {cold }}+273.15\right)}{\left(T_{\text {hot }}+273.15\right)}
$$

Moreover, the effect of the ambient temperature on the capacity of the heat pump must be considered, by means of temperature coefficients $(\kappa)$ :

$$
\begin{gathered}
Q_{R H P-H}=Q_{n o m, R H P-H}\left[1+\kappa_{R H P-H}\left[T_{a m b}-T_{n o m, R H P-H}\right]\right] \\
C_{R H P-C / E C}=C_{n o m, R H P-C / E C}\left[1+\kappa_{R H P-C / E C}\left[T_{n o m, R H P-C / E C}-T_{a m b}\right]\right]
\end{gathered}
$$


where $T_{n o m, R H P-H}=7{ }^{\circ} \mathrm{C}, T_{n o m, R H P-C / E C}=35{ }^{\circ} \mathrm{C}, \kappa_{R H P-H}=0.04 \mathrm{~kW} /{ }^{\circ} \mathrm{C}$ and $\kappa_{R H P-C / E C}=$ $0.015 \mathrm{~kW} /{ }^{\circ} \mathrm{C}$ based on a survey on technical specification sheets by [23].

Based on technical specification sheets [24-27], the following values for the exergy efficiencies have been adopted: $\eta_{e x, R H P-H}=35 \%, \eta_{e x, R H P-C / E C}=29 \%, \eta_{E X, A C}=34 \%$. The part-load correction factors [28] are shown in Figure 3.

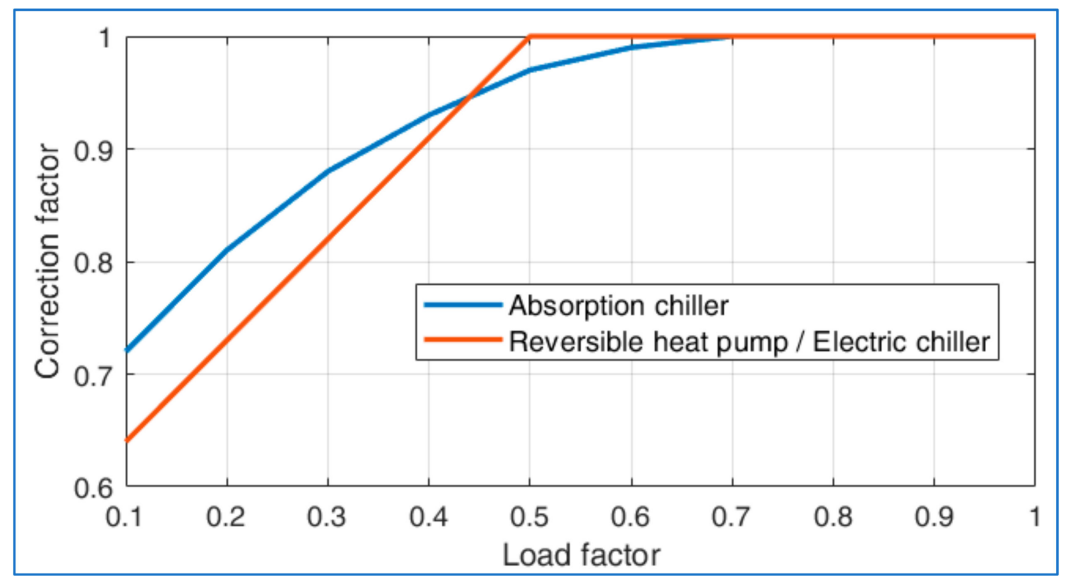

Figure 3. Part-load correction factors for the absorption chiller, reversible heat pump, and electric chiller.

As mentioned, a cooling tower is included in the system to dissipate the heat from the condenser/absorber of the absorption chiller. The inlet temperature of the condenser water (outlet temperature of the cooling tower) changes as the outdoor weather conditions vary (i.e., as the ambient wet bulb temperature varies). The so called "fixed approach control" method has been considered as the control method of the cooling tower. Such a method consists in varying the cooling tower air flow rate to maintain a constant temperature difference between the cooling tower outlet water temperature and the ambient air wet bulb temperature [18]. This temperature difference is commonly known as "approach". Therefore, the inlet temperature of the cooling water circuit of the absorption chiller can be evaluated as the sum of the ambient air wet bulb temperature and the approach temperature, set at $6{ }^{\circ} \mathrm{C}$. The electric power consumption due to cooling tower fans is evaluated as $0.026 \mathrm{~kW}$ per $\mathrm{kW}$ of heat rejection capacity [29].

The natural-gas boiler has a nominal efficiency of $90 \%$ and it has been modelled considering part-load efficiency, as follows [30]:

$$
\eta_{B}=0.9\left(0.0951+1.525 L_{B}-0.6249 L_{B}^{2}\right)
$$

The PV generator has been modeled by considering the ambient temperature and solar irradiance; the output power is evaluated as follows [31].

$$
E_{P V}=E_{P V, S T C} \frac{G}{G_{S T C}}\left[1-\gamma\left[T_{\text {cell }}-25\right]\right]
$$

where $P_{P V, S T C}$ is the rated power of the PV generator at standard test conditions (STC), G is the solar irradiance $\left(\mathrm{kW} / \mathrm{m}^{2}\right), \gamma$ is the power temperature coefficient, and $T_{\text {cell }}$ is the cell temperature. The STC are $T_{\text {cell,STC }}=25^{\circ} \mathrm{C}, G_{S T C}=1 \mathrm{~kW} / \mathrm{m}^{2}$, and wind speed of $1 \mathrm{~m} / \mathrm{s}$. The cell temperature $T_{\text {cell }}$ is obtained as follows.

$$
T_{\text {cell }}=T_{\text {amb }}+\frac{G}{0.8}(N O C T-20)
$$

where $T_{a m b}$ is the ambient temperature and NOCT is the nominal operating cell temperature. In this paper, the PV generator is composed of polycrystalline modules that have all been considered to be at the same temperature. The temperature coefficient $\gamma$ is $0.043 \% /{ }^{\circ} \mathrm{C}$, and the NOCT is $45.5^{\circ} \mathrm{C}$ [31]. 
The electrical power output of the horizontal-axis wind turbine $E_{W T}$ has been evaluated as follows [32].

$$
\left\{\begin{array}{cr}
E_{W T}=0 & \left(v \leq v_{\text {cut }- \text { in }}\right) \\
E_{W T}=E_{n o m}\left\{v^{k}-v_{c u t-i n}^{k} /\left(v_{\text {nom }}^{k}-v_{c u t-i n}^{k}\right)\right. & \left(v_{\text {cut }-i n} \leq v \leq v_{\text {nom }}\right) \\
E_{W T}=E_{\text {nom }} & \left(v_{\text {nom }} \leq v \leq v_{\text {cut }- \text { off }}\right) \\
E_{W T}=0 & \left(v>v_{\text {cut }- \text { off } f}\right)
\end{array}\right.
$$

where $v$ is the wind speed and $k$ is the Weibull shape parameter of the wind speed distribution [32]. The wind speed data, usually recorded at $10 \mathrm{~m}$, must be corrected to consider the turbine hub height, as follows:

$$
v=v_{\text {reference height }} \frac{\log \left(z_{\text {turbine hub }} / z_{0}\right)}{\log \left(z_{\text {reference }} / z_{0}\right)}
$$

where $z_{0}$ is the roughness length, which depends on the terrain characteristics.

\subsection{Optimization Problem and Method}

The objective function to be minimized is the Equivalent Annual Cost (EAC) of the system, which is calculated over the period of a year and composed of the annualized investment cost for the technologies, Invest, and the total annual operating cost, $O p$.

$$
\begin{gathered}
E A C: f=\text { Invest }+O p \\
\text { Invest }=\sum_{i} a_{i} C A P_{i}^{b_{i}} C R F_{i}
\end{gathered}
$$

where $C A P_{i}$ is the capacity of the $i$ th technology to be installed (expressed in $\left.\mathrm{kW}\right), a_{i}$ and $b_{i}$ are the correlation parameters of the equipment cost as a function of the capacity, and CRF is the capital-recovery factor.

$$
C R F=\frac{r(r+1)^{\text {lifetime }}}{(r+1)^{\text {lifetime }}-1}
$$

The total annual operating cost comprises the cost for purchasing electricity and natural gas and the revenue from selling electricity to the grid. An hourly timestep has been considered.

$$
O p=\sum_{t=1}^{8760}\left[c_{F}\left[F_{I C E, t}+F_{B, t}\right]+c_{P E} E_{P, t}-c_{S E} E_{S, t}\right]
$$

Demand constraints must be satisfied in each $t$ th time step.

$$
\begin{gathered}
E_{I C E, t}+E_{P V, t}+E_{W T, t}+E_{P, t}-E_{S, t}-E_{E C / R H P-C, t}-E_{R H P-H, t}-E_{C T, t}=E_{D, t} \\
Q_{I C E, t}+Q_{B / R H P-H, t} \geq Q_{D, t} \\
C_{A C, t}+C_{E C / R H P-C, t} \geq 0
\end{gathered}
$$

where $t=1,2, \ldots, 8760$, and the electric consumption due to the cooling-tower fans depends on the amount of heat to be rejected from the absorption chiller:

$$
E_{C T, t}=C_{A C, t} \frac{\left(1+C O P_{A C, t}\right)}{C_{A C}, t} \varepsilon_{C T}
$$

Governing equations and capacity constraints must also be considered:

$$
\begin{aligned}
& E_{I C E, t} \leq E_{I C E, n o m} \delta_{I C E, t} \\
& E_{I C E, t} \geq E_{I C E, \min } \delta_{I C E, t}
\end{aligned}
$$




$$
\begin{gathered}
F_{I C E, t}=E_{I C E, t} / \eta_{E, I C E, t} \\
Q_{I C E, t}=E_{I C E, t} \frac{\eta_{H, I C E, t}}{\eta_{E, I C E, t}} \\
C_{A C, t}=Q_{I C E, t} / C O P_{A C, t} \\
C_{A C, n o m}=E_{I C E, n o m} \eta_{H, I C E, \text { nom }} C O P_{A C, n o m} \\
Q_{B, t} \leq Q_{B, \text { nom }} \\
F_{B, t} \leq Q_{B, t} / \eta_{B, t} \\
E_{E C, t} \leq E_{E C, n o m} \\
E_{E C / R H P-C, t}=C_{E C / R H P-C, t} / C O P_{E C / R H P-C, t} \\
E_{R H P-H, t}=Q_{R H P-H, t} / C O P_{R H P-H, t} \\
Q_{R H P-H, t} C_{R H P-C, t}=0 \\
E_{R H P, t} \leq E_{R H P, n o m} \\
C_{R H P-C, \text { nom }} / C O P_{R H P-C, n o m}=Q_{R H P-H, n o m} / C O P_{R H P-H, n o m}
\end{gathered}
$$

where $t=1,2, \ldots, 8760$.

Ultimately, the overall problem consists in the minimization of the Equivalent Annual Cost:

$$
\text { minimize }\{f=E A C\}
$$

which results in a mixed integer non-linear optimization problem.

To solve this optimization problem, a two-stage algorithm has been specifically developed, which is schematically summarized in Figure 4 . The optimization variables can be distinguished in two main groups: sizing variables (i.e., $\left.E_{I C E, n o m}, Q_{B, n o m}, C_{E C, n o m}, Q_{R H P-H, n o m}, E_{P V}, E_{W T}\right)$ and operation variables (i.e., $E_{I C E, t}, C_{E C / R H P-C, t}, Q_{B / R H P-H, t}, E_{S, t}, E_{P, t}, C_{A C, t}$ with $\left.t=1, \ldots, 8760\right)$. Therefore, the problem can be decomposed into two levels: the upper level, where the optimal capacity of each energy unit is identified, and the lower level, where the optimal operating conditions of the system in each timestep are found. Obviously, the two problems must be solved simultaneously.

At the upper level, the sizing problem is addressed by means of a Genetic Algorithm, which is a widely used optimization tool for the design of DESs [33]. Clearly, it is also possible that in the optimal solution a technology is not included in the system, i.e., its resulting optimal size is null. At the lower level, since the operation problem under analysis is static, it can be solved by means of a "greedy approach" [18,34]. That means the overall operation problem can be split into 8760 sub-problems, one for each timestep, to be solved independently. Then, for each timestep, the problem is reduced to find the optimal load factor of the ICE. Indeed, once the load factor of the ICE is set, the ICE heating production and the cooling production by the absorption chiller are known. Therefore, the back-up units (either the boiler and the non-reversible electric chiller, or the reversible heat pump) just need to meet the remaining thermal demand, if any. The electric balance is also trivial, once the load factor of the ICE is set, since the production by RES in each timestep is also known. Consequently, the optimal operation problem consists in finding the optimal load factor of the ICE, in each timestep. This task is fulfilled with an exhaustive-search, which guarantees the global optimality of the solution. 


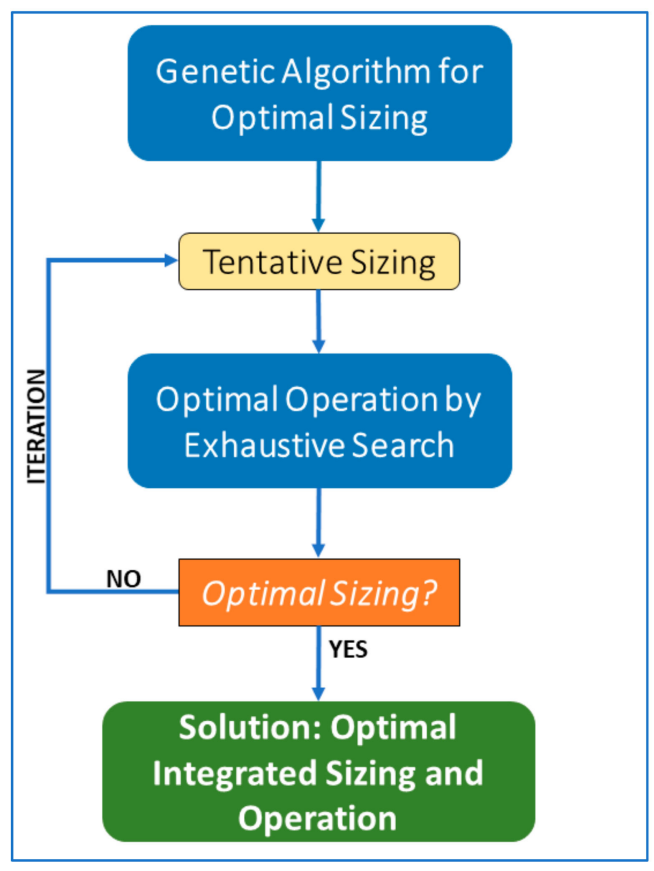

Figure 4. Optimization procedure.

All the simulations and optimization are performed using scripts written in MATLAB environment. The MATLAB Genetic Algorithm Solver [35] is used, whose settings and stopping criteria are shown in Table 1. A simple in-house code is adopted to implement the greedy approach, and a 0.05 step in the load factor of the ICE is considered in the exhaustive search.

Table 1. Settings and parameters adopted for the Genetic Algorithm.

\begin{tabular}{|c|c|c|c|c|}
\hline $\begin{array}{c}\text { PopulationSize } \\
250\end{array}$ & $\begin{array}{c}\text { EliteCount } \\
10\end{array}$ & $\begin{array}{l}\text { TolFun } \\
1 e-6\end{array}$ & $\begin{array}{c}\text { CrossoverFraction } \\
0.8\end{array}$ & $\begin{array}{c}\text { MigrationDirection } \\
\text { 'forward' }\end{array}$ \\
\hline $\begin{array}{l}\text { StallGenLimit } \\
50\end{array}$ & $\begin{array}{c}\text { Generations } \\
400\end{array}$ & $\begin{array}{l}\text { TolCon } \\
1 e-3\end{array}$ & $\begin{array}{c}\text { MigrationFraction } \\
0.2\end{array}$ & $\begin{array}{c}\text { MigrationInterval } \\
20\end{array}$ \\
\hline
\end{tabular}

\section{Case Study: Energy Demand and Economic Parameters}

Both energy system configurations under analysis have been tested in a case study. Energy demand data of a large office building located in Pisa (Italy) have been considered. The office is located in an 8 -story building, with a gross volume about $73,000 \mathrm{~m}^{3}$ and a floor area about $24,000 \mathrm{~m}^{2}$, having $25-\mathrm{cm}$ concrete walls and double-glazed windows (the window-to-wall ratio is 0.16 ). DHW demand is met by small local electrically driven heaters, so the plant must satisfy only space heating and cooling requirements. The complete low-temperature district heating and cooling network is not modelled. Just to test the viability of the energy supply plant using reversible heat pumps, the energy demand is simplified to cover the demand of an office building that could be representative of the energy profiles expected to be covered in urban DHC networks. The proposed methodology and system configuration could be easily applied to a bigger-scale system. Figure 5 shows the hourly energy demand data for the case study. Three energy services are needed: electricity, cooling (chilled water from 7 to $12{ }^{\circ} \mathrm{C}$ ) and heating (hot water from 45 to $35^{\circ} \mathrm{C}$ ). Hourly data of electricity consumption were available from measurements, while thermal load demands were evaluated by a dynamic simulation in TRNSYS 17. The hourly profiles of the external temperature, relative humidity, solar irradiance, and wind speed of the typical meteorological year [36] of Pisa have been adopted. 


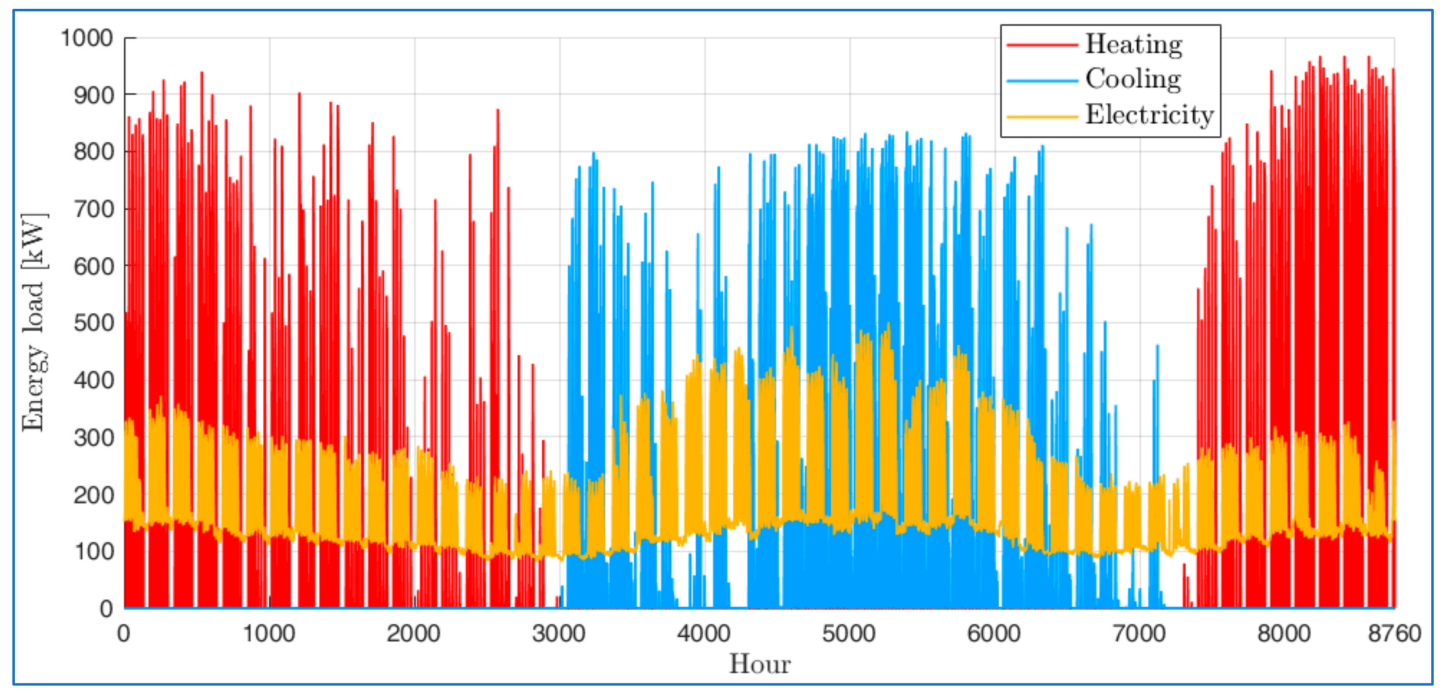

Figure 5. Hourly energy demand data of the case study.

Table 2 shows the values of all the economic parameters adopted in the simulations. The considered lifetime for all technologies is 20 years [13].

Table 2. Price of energy carriers and investment cost parameters (used in Equations (13)-(15)).

\begin{tabular}{cccccccc}
\hline Parameter & Value & Parameter & Value & Parameter & Value & Parameter & Value \\
\hline$a_{I C E}$ & $7789[13]$ & $b_{C T}$ & $1[37]$ & $a_{B}$ & $345.9[38]$ & $b_{W T}$ & $1[39]$ \\
$b_{I C E}$ & $0.6[13]$ & $a_{R H P}$ & $1036[23]$ & $b_{B}$ & $0.79[38]$ & $r$ & $7 \%[13]$ \\
$a_{A C}$ & $375[40]$ & $b_{R H P}$ & $0.74[23]$ & $a_{P V}$ & $1500[39]$ & $c_{F}$ & $0.052 € / \mathrm{kWh}[41]$ \\
$b_{A C}$ & $0.65[40]$ & $a_{E C}$ & $609[23]$ & $b_{P V}$ & $1[39]$ & $c_{P E}$ & $0.166 € / \mathrm{kWh}[41]$ \\
$a_{C T}$ & $28.75[40]$ & $b_{E C}$ & $0.79[23]$ & $a_{W T}$ & $1570[39]$ & $c_{S E}$ & $0.040 € / \mathrm{kWh}[13]$ \\
\hline
\end{tabular}

\section{Results}

In this section, the results of the integrated optimal sizing and operation in terms of Equivalent Annual Cost are shown and discussed. As mentioned, the optimization has been performed for both the energy system configurations shown in Figure 1, i.e., the proposed configuration with a reversible heat pump as single thermal back-up unit, and the traditional configuration with a boiler and a non-reversible electric chiller as thermal back-up units. Table 3 summarizes the main results obtained from the optimizations. In the evaluation of the carbon dioxide emissions, the values of the carbon intensity of the electricity from the grid and the natural gas are 325.2 and $202.0 \mathrm{~g}_{\mathrm{CO} 2 \mathrm{eq}} / \mathrm{kWh}$, respectively [42].

Table 3. Optimal Equivalent Annual Cost: sizing and operation-results.

\begin{tabular}{ccc}
\hline Energy System Configuration & $\begin{array}{c}\text { Novel Configuration with } \\
\text { Reversible Heat Pump }\end{array}$ & $\begin{array}{c}\text { Traditional Configuration with } \\
\text { Boiler and Non-Reversible } \\
\text { Electric Chiller }\end{array}$ \\
\hline $\begin{array}{c}\text { Internal Combustion Engine (Nominal Electric Power) } \\
\text { Absorption Chiller } \\
\text { (Cooling Capacity) }\end{array}$ & $165 \mathrm{~kW}$ & $250 \mathrm{~kW}$ \\
Reversible Heat Pump (Heating/Cooling Capacity) \\
$\begin{array}{c}\text { Boiler (Heating Capacity) } \\
\text { Electric Chiller } \\
\text { (Cooling Capacity) } \\
\text { Photovoltaic Panels } \\
\text { (Power at STC) } \\
\text { Wind Turbine } \\
\text { (Nominal Power) }\end{array}$ & $190 \mathrm{~kW}$ & $290 \mathrm{~kW}$ \\
Annual Operating Cost & $\backslash$ & $615 \mathrm{~kW}$ \\
& $505 \mathrm{~kW}$ & $575 \mathrm{~kW}$ \\
& $0 \mathrm{~kW}$ & $410 \mathrm{~kW}$ \\
\end{tabular}


Table 3. Cont.

\begin{tabular}{ccc}
\hline Energy System Configuration & $\begin{array}{c}\text { Novel Configuration with } \\
\text { Reversible Heat Pump }\end{array}$ & $\begin{array}{c}\text { Traditional Configuration with } \\
\text { Boiler and Non-Reversible } \\
\text { Electric Chiller }\end{array}$ \\
\hline Investment Cost & $1199.0 \mathrm{k} €$ & $1138.0 \mathrm{k} €$ \\
Equivalent Annual Cost & $288.8 \mathrm{k} €$ & $310.8 \mathrm{k} €$ \\
Annual Carbon & 580.7 ton & 694.9 ton \\
Dioxide Emissions & & \\
\hline
\end{tabular}

First and foremost, the proposed configuration with reversible heat pump achieves the lowest EAC, with a 7\% saving compared to the traditional configuration. The discounted payback period, considering the initial extra investment and annual cost savings of the proposed configuration compared to the traditional one, is around 2.5 years. Moreover, the installed capacity of RES is $23 \%$ higher in the proposed configuration. This is due to the installation of the reversible heat pump; indeed, the larger share of cooling covered by the RHP compared to the non-reversible electric chiller allows a higher self-consumption of the electricity produced by RES. Both the optimal design solutions do not comprise the wind turbine, because of the low wind speed at the site. For this reason, all the installed RES capacity is represented exclusively by the PV system. Another significant effect of the integration of the reversible heat pump is the low value of the annual carbon dioxide emissions, which is around $11 \%$ lower than that of the traditional configuration. Indeed, the use of natural gas is reduced by $18 \%$ with the integration of the reversible heat pump, as a result of the elimination of the boiler and the $34 \%$ downsizing of the internal combustion engine.

Moreover, according to the European Commission Decision establishing the guidelines for Member States on calculating renewable energy from heat pumps [43], part of the energy produced by the heat pump may be considered as renewable energy if the seasonal coefficient of performance (SCOP) is higher than 2.5. In the case study, the SCOP of the reversible heat pump is equal to 3.3. The amount of renewable energy supplied by the reversible heat pump, $\Theta_{R E S, R H P}$, shall be calculated with the following formula:

$$
\Theta_{R E S, R H P}=\Theta_{R H P}\left(1-\frac{1}{S C O P_{R H P}}\right)
$$

where $\Theta_{R H P}$ is the total thermal energy delivered by the heat pump, both heat and cooling. As a result, around $70 \%$ of the energy produced by the reversible heat pump can be considered renewable, for a total of $570 \mathrm{MWh}$. Instead, in the traditional configuration, the electric chiller can be considered to produce only $190 \mathrm{MWh}$ of renewable energy.

Figures 6 and 7 summarizes the annual share of production and consumption of the different energy services (i.e., electricity, heating, and cooling) for the two configurations under analysis. The share of electricity produced by the PV panels increases from the $31.8 \%$ to $36.6 \%$ when the reversible heat pump is included. Moreover, the amount of electricity sold to the grid remains approximately the same, despite the increase of RES installed capacity. Overall, the reversible heat pump plays a key role in covering the heating and cooling demands, with an increase of around 18\% compared to the share covered by the boiler and the non-reversible electric chiller in the traditional configuration. 
(a) Traditional configuration with boiler and non-reversible chiller as back-up units

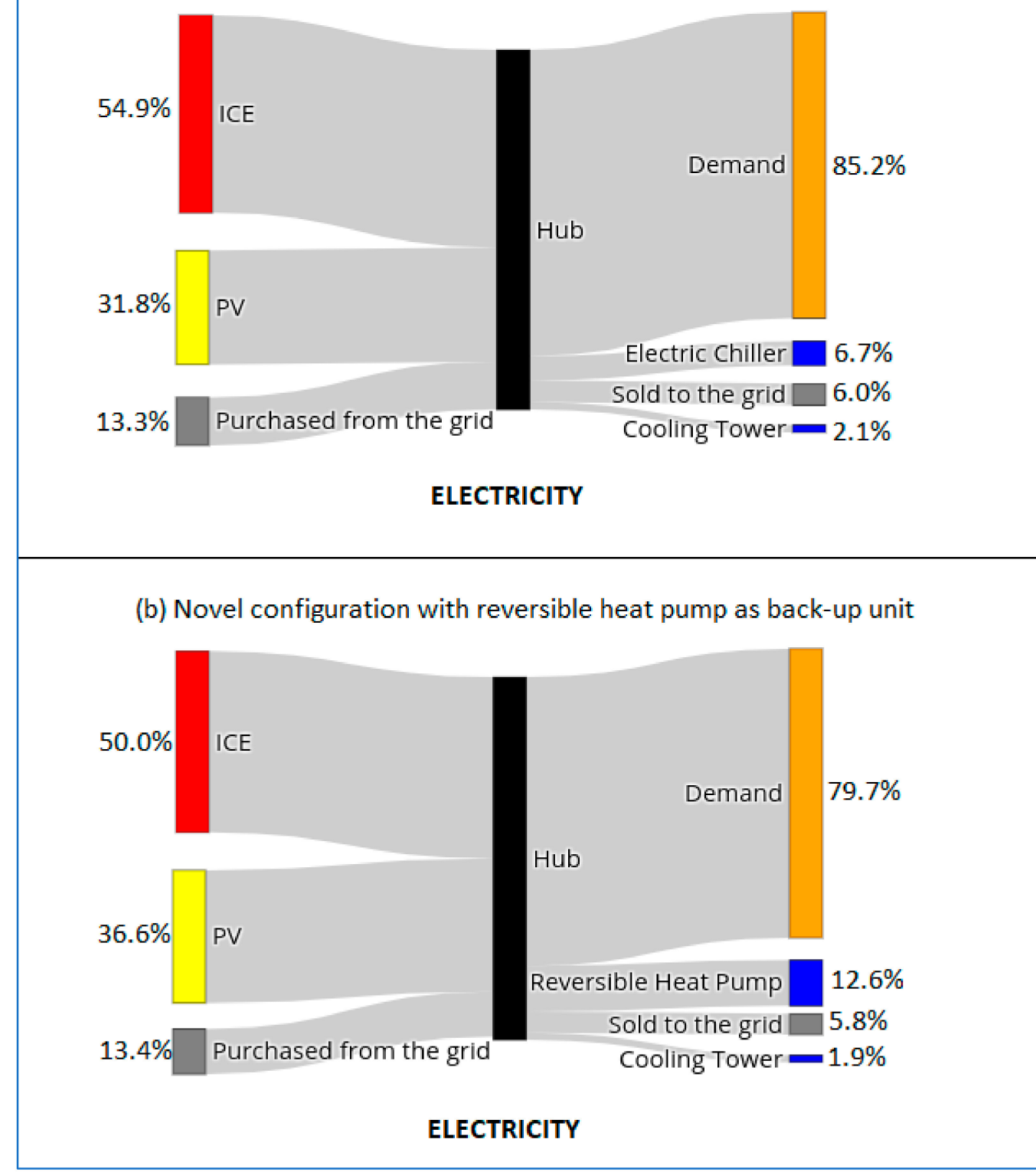

Figure 6. Sankey diagrams of the annual electricity balance for (a) traditional and (b) novel configurations. 
(a) Traditional configuration with boiler and non-reversible chiller as back-up units
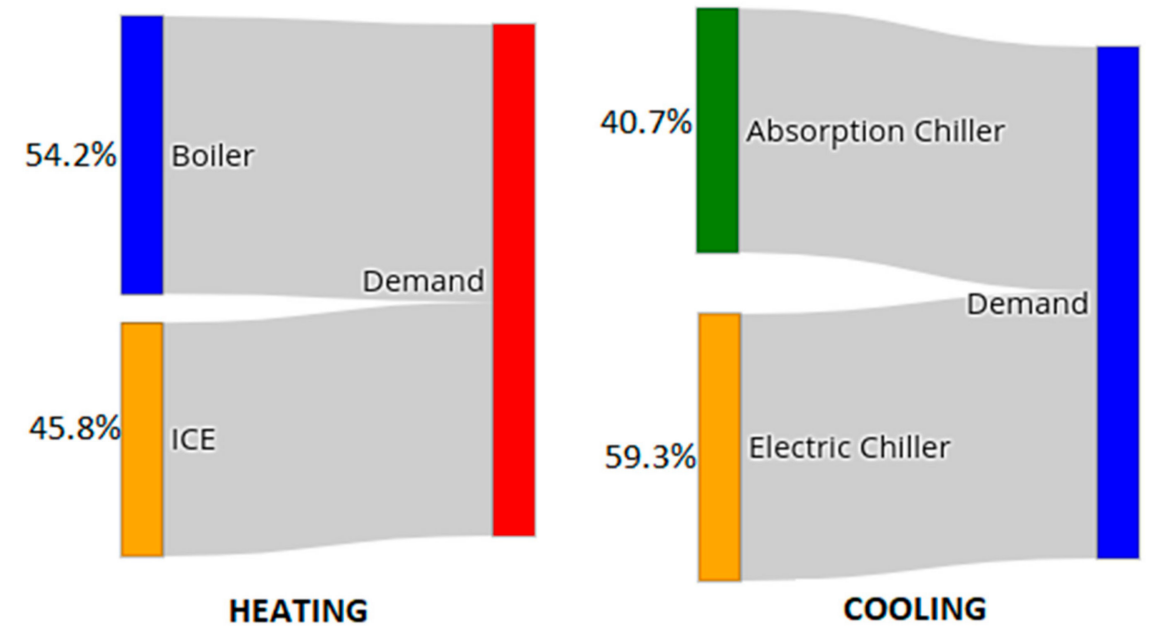

(b) Novel configuration with reversible heat pump as back-up unit

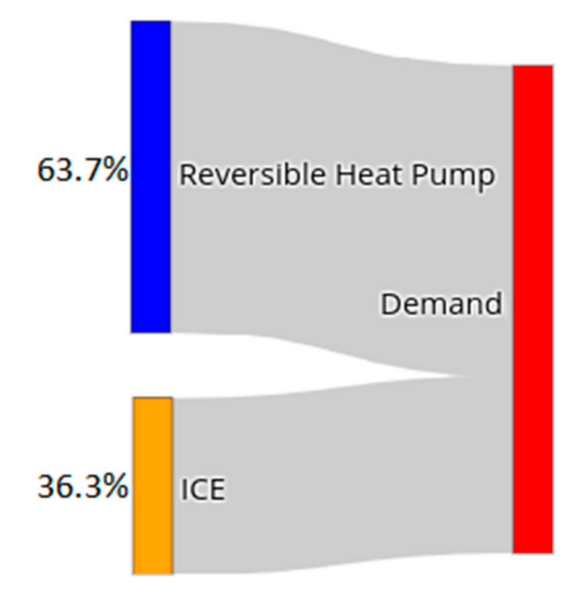

HEATING

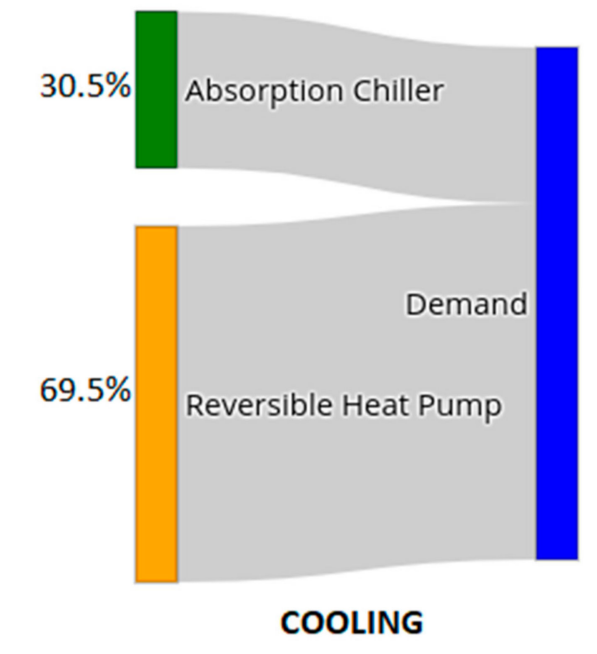

Figure 7. Sankey diagrams of the annual thermal energy balances for (a) traditional and (b) novel configurations.

Finally, Figures 8-11 show how the energy demands (electricity, heating, and cooling) are met, in typical winter and summer weeks, with the novel configuration of the energy system. The internal combustion engine is generally continuously on to cover the electric base-load, except when the PV production is particularly high. To meet peak-demands, electricity is bought from the grid, while the sale of electricity to the grid only occurs with high PV production. The heating and cooling base-loads are covered by the ICE and the absorption chiller, respectively, while peak-demands are covered by the reversible heat pump during both winter and summer. 


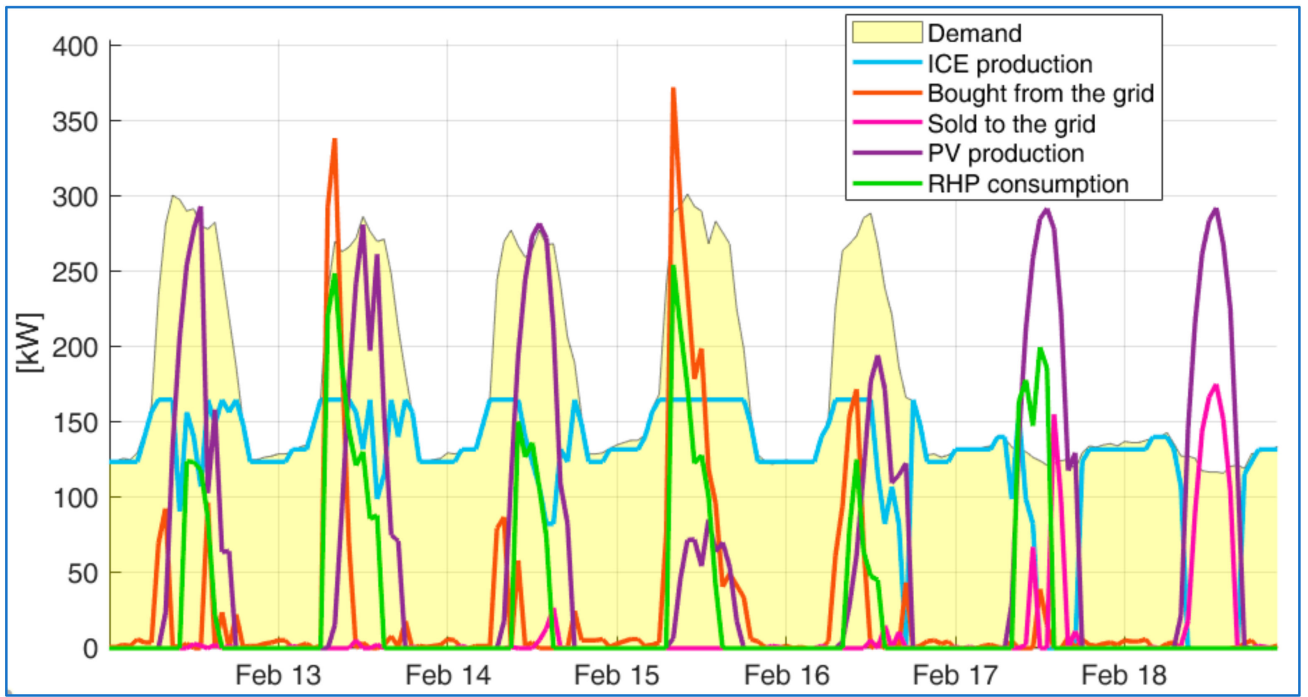

Figure 8. Optimal operation: electricity flows in a typical winter week.

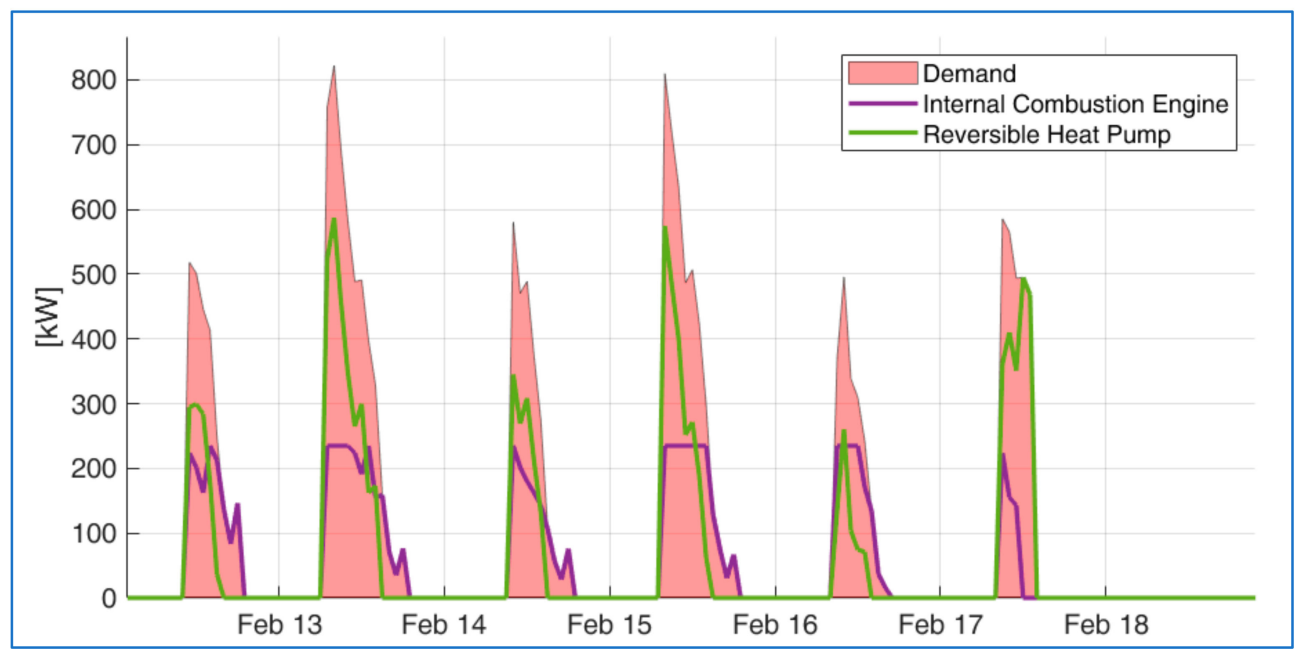

Figure 9. Optimal operation: heating demand and load shares in a typical week.

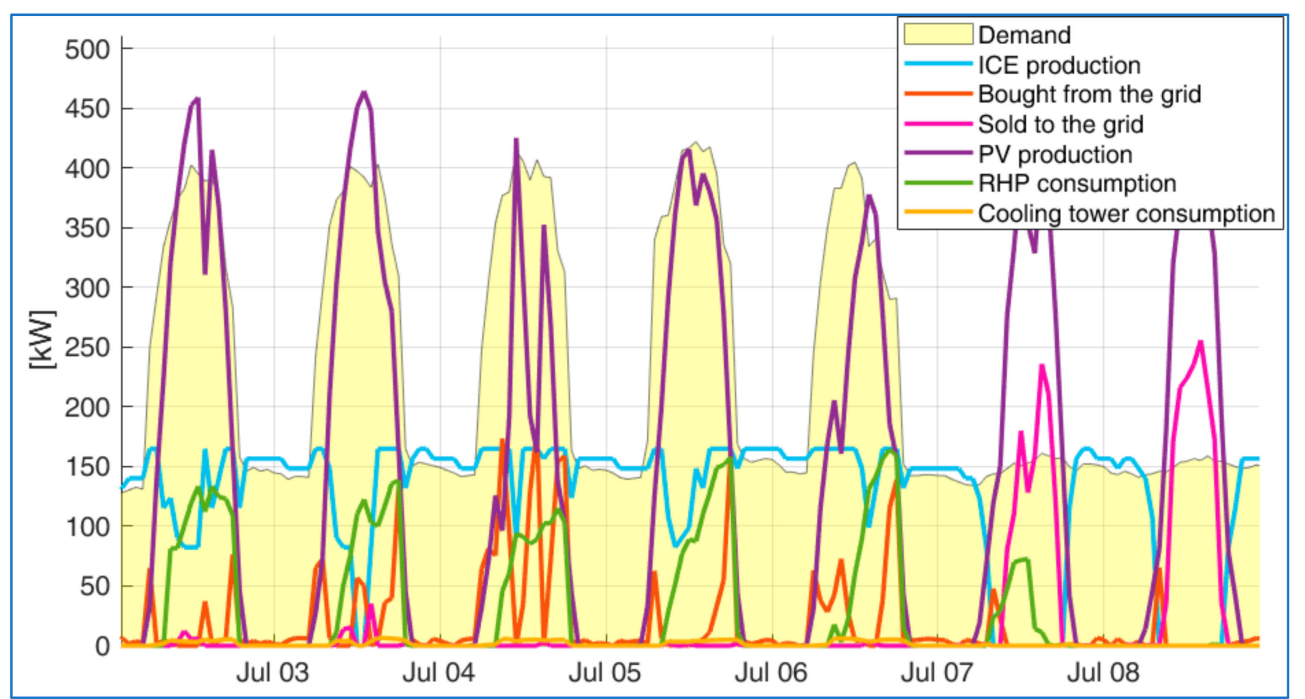

Figure 10. Optimal operation: electricity flows in a typical summer week. 


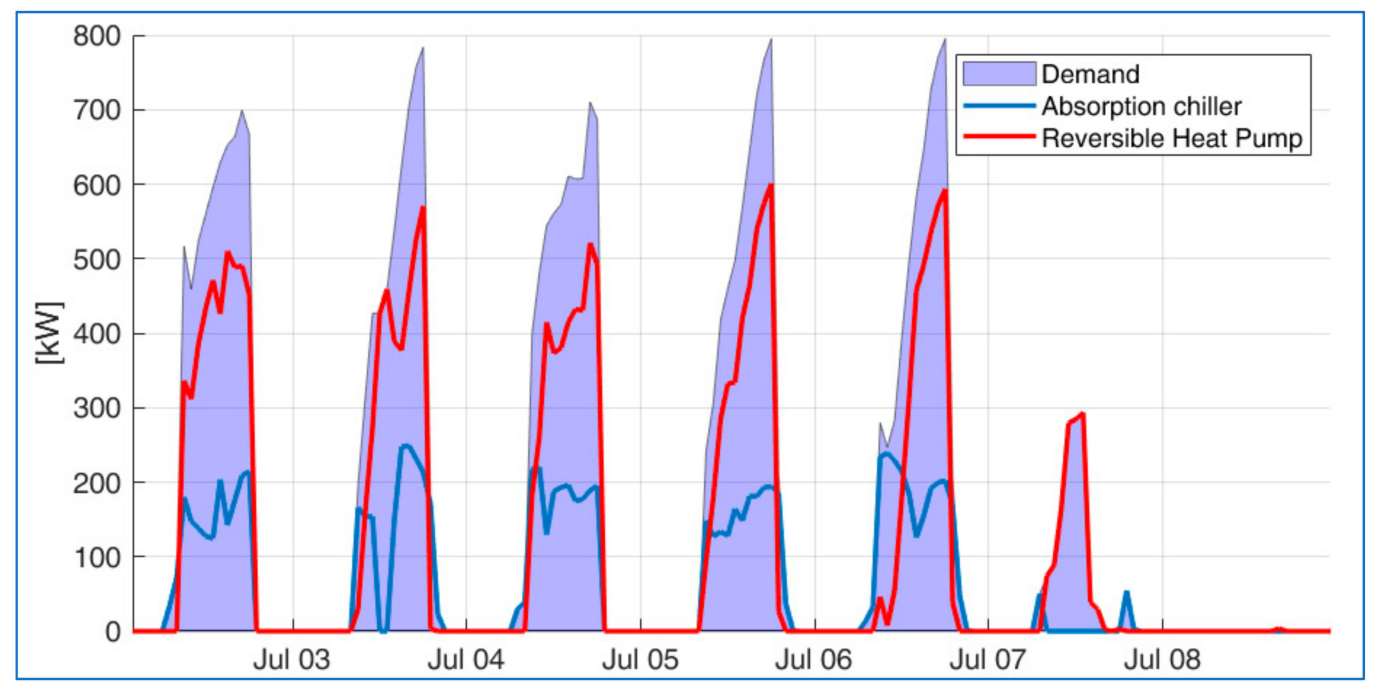

Figure 11. Optimal operation: cooling demand and load shares in a typical week.

Obviously, the performance of the proposed configuration is strongly dependent on weather conditions and demand profiles of the case study. More specifically, a sufficiently high RES availability is needed, so that investment on PV panels or wind turbine is justified. Moreover, both peak and average heating and cooling demands must be comparable, so that the capacity of the reversible heat pump is suitable for both energy services. In summary, the proposed configuration is especially suitable for climates where the heating and cooling seasons are comparable in terms of duration and intensity and the RES electricity production is significant.

\section{Conclusions}

The integration of reversible heat pumps in hybrid renewable trigeneration systems serving low-energy district heating and cooling microgrids was proposed and investigated in this paper. Traditional thermal back-up units, i.e., natural gas boiler and non-reversible electric chiller, have been replaced by an electrically driven reversible heat pump as single thermal back-up unit. The energy system also includes an internal combustion engine, an absorption chiller, photovoltaic panels, and a wind turbine.

The proposed configuration was compared to the benchmark configuration of hybrid trigeneration system with conventional back-up units. A case study was considered, and the integrated optimal sizing and operation were identified by means of a genetic algorithm-based procedure. The proposed configuration achieved the best economic performance, with a $7 \%$ saving in the equivalent annual cost. Moreover, with the integration of the reversible heat pump, a $23 \%$ higher capacity of renewables was installed in the optimal design of the system. As a result, annual carbon dioxide emissions were lowered by $11 \%$ compared to the traditional configuration.

Overall, the integration of electrically driven reversible heat pumps in trigeneration systems was found to be an economically viable solution capable of increasing the share of renewables, reducing the use of fossil fuels, and lowering greenhouse gas emissions.

Author Contributions: Conceptualization: L.U., D.T. and J.C.B.; Methodology: L.U. and D.T.; Software: L.U.; Data curation: L.U.; Writing-original draft: L.U.; Writing-review \& editing: L.U., D.T. and J.C.B.; Supervision: D.T. and J.C.B.

Funding: This research received no external funding.

Conflicts of Interest: The authors declare no conflicts of interest. 


\section{Nomenclature}

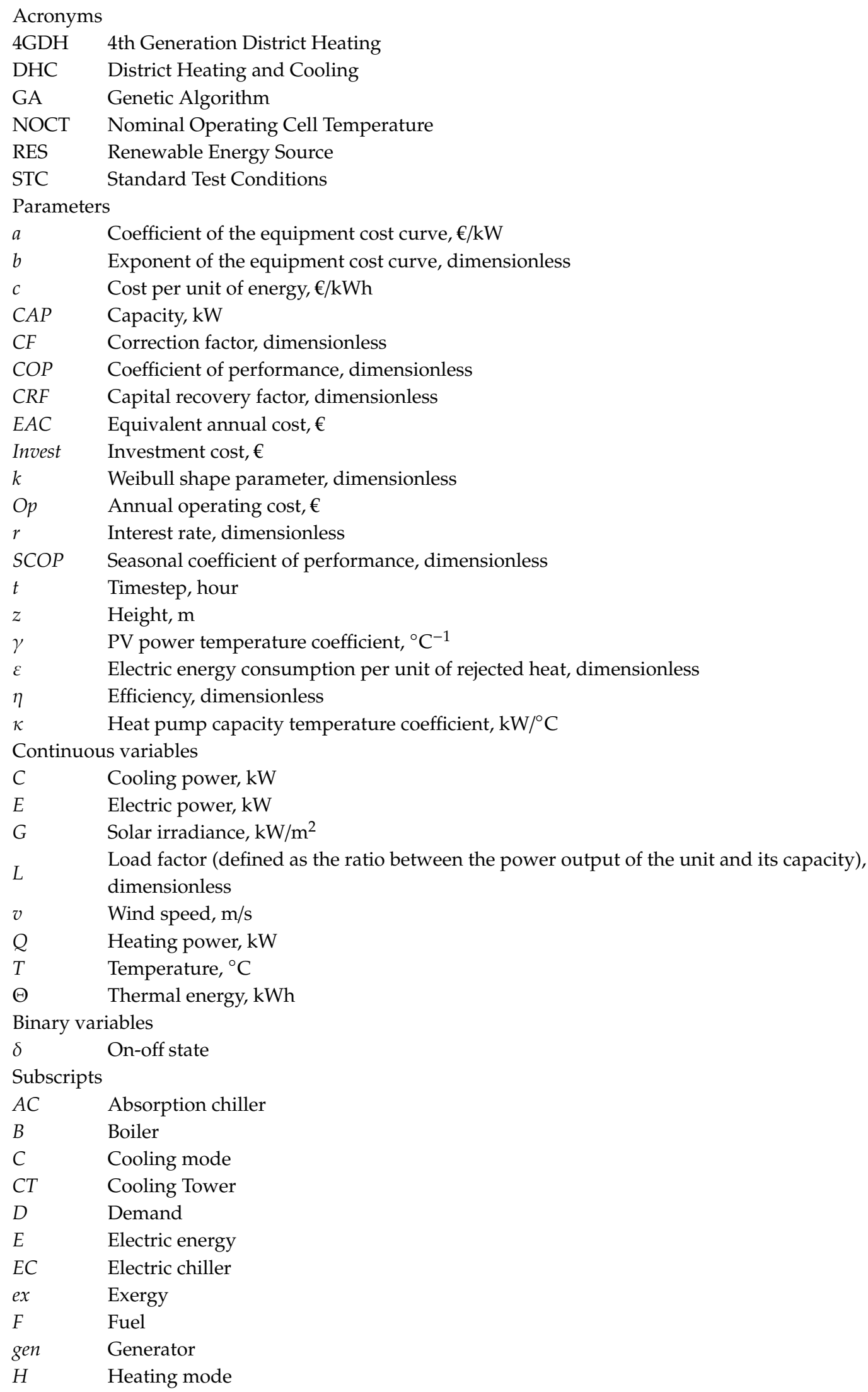




$\begin{array}{ll}\text { ICE } & \text { Internal Combustion Engine } \\ \text { nom } & \text { Nominal } \\ P & \text { Purchased from the grid } \\ P V & \text { PhotoVoltaics } \\ \text { RHP } & \text { Reversible Heat Pump } \\ S & \text { Sold to the grid } \\ \text { WT } & \text { Wind Turbine }\end{array}$

\section{References}

1. International Energy Agency (IEA). Global Energy and CO2 Status Report 2018. Available online: https: //www.iea.org/geco (accessed on 5 August 2019).

2. Lund, H.; Østergaard, P.A.; Connolly, D.; Mathiesen, B.V. Smart energy and smart energy systems. Energy 2017, 137, 556-565. [CrossRef]

3. Karmellos, M.; Georgiou, P.N.; Mavrotas, G. A comparison of methods for the optimal design of Dsitrbuted Energy Systems under uncertainty. Energy 2019, 178, 318-333. [CrossRef]

4. Werner, S. International review of district heating and cooling. Energy 2017, 137, 617-631. [CrossRef]

5. Buffa, S.; Cozzini, M.; D'Antoni, M.; Baratieri, M.; Fedrizzi, R. 5th generation district heating and cooling systems: A review of existing cases in Europe. Renew. Sustain. Energy Rev. 2019, 104, 504-522. [CrossRef]

6. Lund, H.; Werner, S.; Wiltshire, R.; Svendsen, S.; Thorsen, J.E.; Hvelpund, F.; Vad Mathiesen, B. 4th Generation District Heating (4GDH) Integrating smart thermal grids into future sustainable energy systems. Energy 2014, 68, 1-11. [CrossRef]

7. Sameti, M.; Haghighat, F. Optimization of 4th generation distributed district heating system: Design and planning of combined heat and power. Renew. Energy 2019, 130, 371-387. [CrossRef]

8. Cai, H.; You, S.; Wang, J.; Bindner, H.W.; Klyapovskiy, S. Technical assessment of electric heat boosters in low-temperature district heating based on combined heat and power analysis. Energy 2018, 150, $938-949$. [CrossRef]

9. Baldvinsson, I.; Nakata, T. A feasibility and performance assessment of a low temperature district heating system-a North Japanese case study. Energy 2016, 95, 155-174. [CrossRef]

10. Sameti, M.; Haghighat, F. Optimization approaches in district heating and cooling thermal network. Energy Build. 2017, 140, 121-130. [CrossRef]

11. Inayat, A.; Raza, M. District cooling system via renewable energy sources: A review. Renew. Sustain. Energy Rev. 2019, 107, 360-373. [CrossRef]

12. Soltero, V.M.; Chacartegui, R.; Ortiz, C.; Lizana, J.; Quirosa, G. Biomass District Heating Systems Based on Agriculture Residues. Appl. Sci. 2018, 8, 476. [CrossRef]

13. Testi, D.; Conti, P.; Schito, E.; Urbanucci, L.; D'Ettorre, F. Synthesis and Optimal Operation of Smart Microgrids Serving a Cluster of Buildings on a Campus with Centralized and Distributed Hybrid Renewable Energy Units. Energies 2019, 12, 745. [CrossRef]

14. Kang, L.G.; Yang, J.H.; An, Q.S.; Deng, S.; Zhao, J.; Li, Z.L.; Wang, Y.Z. Complementary configuration and performance comparison of CCHP-ORC system with a ground source heat pump under different operation strategies. Energy Convers. Manag. 2017, 135, 244-255. [CrossRef]

15. Ommen, T.S.; Markussen, W.B.; Elmegaard, B. Heat pumps in combined heat and power systems. Energy 2014, 76, 989-1000. [CrossRef]

16. Sayegh, M.; Jadwiszczak, P.; Axcell, B.; Niemierka, E.; Brys, K.; Jouhara, H. Heat pump placement, connection and operational modes in European district heating. Energy Build. 2018, 166, 122-144. [CrossRef]

17. Ostergaard, P.A.; Jantzen, J.; Marczinkowski, H.M.; Kristensen, M. Business and socioeconomic assessment of introducing heat pumps with heat storage in small-scale district heating systems. Renew. Energy 2019, 139, 904-914. [CrossRef]

18. Urbanucci, L.; Testi, D.; Bruno, J. An operational optimization method for a complex polygeneration plant based on real-time measurements. Energy Convers. Manag. 2018, 170, 50-61. [CrossRef] 
19. Kinab, E.; Marchio, D.; Rivière, P.; Zoughaib, A. Reversible heat pump model for seasonal performance optimization. Energy Build. 2010, 42, 2269-2280. [CrossRef]

20. Madonna, F.; Bazzocchi, F. Annual performances of reversible air-to-water heat pumps in small residential buildings. Energy Build. 2013, 65, 299-309. [CrossRef]

21. Dongellini, M.; Naldi, C.; Morini, G.L. Sizing effects on the energy performance of reversible air-source heat pumps for office buildings. Appl. Therm. Eng. 2017, 114, 1073-1081. [CrossRef]

22. Ebrahimi, M.; Keshavarz, A. Combined Cooling, Heating and Power: Decision-Making, Design and Optimization; Elsevier: Amsterdam, The Netherlands, 2015.

23. Cinquini, F. Dimensionamento e Gestione Ottimizzati di Sistemi a Pompa di Calore Aria-Acqua per la Climatizzazione Annuale di Edifici Terziari. Master's Thesis, University of Pisa, Pisa, Italy, 2018.

24. Aermec. Heat Pumps and Chillers: Catalogue and Technical Documentation. Available online: https: //support.aermec.com/default.asp (accessed on 5 August 2019).

25. Galletti. Heat Pumps and Chillers: Catalogue and Technical Documentation. Available online: http: //www.galletti.com/users/login-utente (accessed on 5 August 2019).

26. Rossato. Heat Pumps and Chillers: Catalogue and Technical Documentation. Available online: https://www. rossatogroup.com/prodotti/pompe-di-calore/pompe-di-calore-aria-acqua.html (accessed on 5 August 2019).

27. YORK. Heat Pumps and Chillers: Catalogue and Technical Documentation. Available online: https://www.johnsoncontrols.com/-/media/jci/global-capabilities/be/files/be_york_industrial_commercial_ hvac_2018.pdf (accessed on 5 August 2019).

28. European Committee for Standardization. Heating Systems in Buildings-Method for Calculation of System Energy Requirements and System Efficiencies-Part 4-2: Space Heating Generation Systems, Heat Pump Systems; EN 15316-4-2; CEN: Brussels, Belgium, 2017.

29. DiPippo, R. Geothermal Power Generation: Developments and Innovation; Woodhead Publishing: Sawston/Cambrige, UK, 2016.

30. Zhou, Z.; Liu, P.; Li, Z.; Pistikopoulos, E.N.; Georgiadis, M.C. Impacts of equipment off-design characteristics on the optimal design and operation of combined cooling, heating and power systems. Comput. Chem. Eng. 2013, 48, 40-47. [CrossRef]

31. Riffonneau, Y.; Bacha, S.; Barruel, F.; Ploix, S. Optimal Power Flow Management for Grid Connected PV Systems with Batteries. IEEE Trans. Sustain. Energy 2011, 2, 309-320. [CrossRef]

32. Borowy, B.S.; Salameh, Z.M. Optimum photovoltaic array size for a hybrid wind/PV system. IEEE Trans. Energy Convers. 1994, 9, 482-488. [CrossRef]

33. Abdmouleh, Z.; Gastli, A.; Ben-Brahim, L.; Haouari, M.; Al-Emadi, N.A. Review of optimization techniques applied for the integration of distributed generation from renewable energy sources. Renew. Energy 2017, 113, 266-280. [CrossRef]

34. Urbanucci, L.; Testi, D. Optimal integrated sizing and operation of a CHP system with Monte Carlo risk analysis for long-term uncertainty in energy demands. Energy Convers. Manag. 2018, 157, 307-316. [CrossRef]

35. MATLAB. Genetic Algorithm Solver. Available online: https://it.mathworks.com/discovery/genetic-algorithm. html (accessed on 5 August 2019).

36. Italian Thermotechnical Committee (CTI). National Typical Meteorological Years; CTI: Milan, Italy, 2016.

37. Carvalho, M.; Lozano, M.A.; Ramos, J.; Serra, L.M. Synthesis of Trigeneration Systems: Sensitivity Analyses and Resilience. Sci. World J. 2013, 2013, 1-16. [CrossRef]

38. Urbanucci, L.; D'Ettorre, F.; Testi, D. A Comprehensive Methodology for the Integrated Optimal Sizing and Operation of Cogeneration Systems with Thermal Energy Storage. Energies 2019, 12, 875. [CrossRef]

39. Renewable Energy Report, Politecnico di Milano. 2018. Available online: http://www.energystrategy.it/ report/renewable-energy-report.html (accessed on 5 August 2019).

40. Urbanucci, L.; Bruno, J.C.; Testi, D. Thermodynamic and economic analysis of the integration of high-temperature heat pumps in trigeneration systems. Appl. Energy 2019, 238, 516-533. [CrossRef]

41. Eurostat, European Commission. Energy Statistics-Prices of Natural Gas and Electricity. Available online: https://ec.europa.eu/eurostat/web/energy/data/database (accessed on 5 August 2019). 
42. Energy efficiency report 2018, Politecnico di Milano. Available online: http://www.energystrategy.it/assets/ files/EER_18_web.pdf (accessed on 5 August 2019).

43. Commission Decision of 1 March 2013 establishing the guidelines for Member States on calculating renewable energy from heat pumps from different heat pump technologies pursuant to Article 5 of Directive 2009/28/EC of the European Parliament and of the Council. Official Journal of the European Union 2013, 62, 27, Decision 2013/114/EU. Available online: https://eur-lex.europa.eu/legal-content/EN/TXT/PDF/?uri=CELEX: 32013D0114\&from=EN (accessed on 5 August 2019).

C 2019 by the authors. Licensee MDPI, Basel, Switzerland. This article is an open access article distributed under the terms and conditions of the Creative Commons Attribution (CC BY) license (http://creativecommons.org/licenses/by/4.0/). 